\title{
New occurrences of dragonflies in the Atlantic Forest fragments of Santa Teresa, Espírito Santo, Brazil
}

\author{
Arianny P. Storari ${ }^{1}{ }^{*}$, Diego Pereira ${ }^{1}$ and Karina S. Furieri ${ }^{2}$ \\ ${ }^{1}$ Departamento de Ciências Biológicas. Centro de Ciências Humanas e Naturais. \\ Universidade Federal do Espírito Santo. Avenida Fernando Ferrari, 514. \\ Goiabeiras. Vitória-ES, Brasil (CEP 29075-910). *Email: ariannystorari@gmail.com. \\ ${ }^{2}$ Departamento de Ciências Agrárias e Biológicas. Centro Universitário Norte do \\ Espírito Santo. Universidade Federal do Espírito Santo. Rodovia Governador Mário \\ Covas, km 60. Litorâneo. São Mateus-ES, Brasil (CEP 29932-900).
}

\begin{abstract}
One of the greatest obstacles to biodiversity conservation is the lack of information to prioritize efforts on practical actions. This lack of information comes mainly from absence of inventories in many areas where few groups have reasonably complete databases. The distribution of the dragonfly fauna of Brazil is little known - only $29 \%$ of the Brazilian territory presents data about the richness of Odonata. In this contribution, a database of Odonata species of Santa Teresa Municipality was built, Espírito Santo State, Brazil. The database has 627 specimens registered, 77 species distributed in eight families and thirty-eight genera, forty of these species are common, one endemic of the State of Espírito Santo, and nineteen endemic of Brazil. In relation to the measure of conservation, four species are present in the category Insufficient Data (DD), one present in the Nearly Endangered (NT) category, three species in the Vulnerable category (VU) and one in the category In Danger (EN). Twentyfive species are considered new occurrences for the city. These results suggest that the fauna of the studied region deserves attention and points to the interest in implanting future conservation units in the region of Santa Teresa municipality.
\end{abstract}

Keywords: Anisoptera; Odonata; Zygoptera; Conservation; Richness.

Resumo. Novas ocorrências de libélulas nos fragmentos de Mata Atlântica de Santa Teresa, Espírito Santo, Brasil. Um dos maiores obstáculos para a conservação da biodiversidade é a falta de informação para priorizar esforços em ações práticas. Esta falta de informação vem principalmente da ausência de inventários em muitas áreas onde poucos grupos têm bancos de dados razoavelmente completos. A distribuição da fauna de libélula no Brasil é pouco conhecida - apenas $29 \%$ do território brasileiro apresenta dados sobre a riqueza de Odonata. Nesta contribuição, foi construído um banco de dados de espécies de Odonata do Município de Santa Teresa, Estado do Espírito Santo,
Received

May 31, 2019

Accepted

August 29, 2019

Available on line

August 30, 2019

Released

August 31, 2019

Open Access

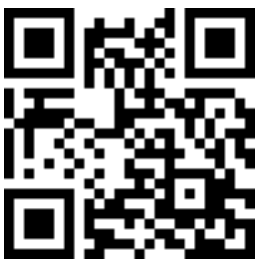

ORCID

(D) 0000-0002-3645-3015 Arianny P. Storari

(D) 0000-0002-4270-7640 Diego Pereira

(1) 0000-0001-6031-8940 Karina S. Furieri 
Brasil. O banco de dados possui 627 exemplares registrados, sendo 77 espécies distribuídas em oito famílias e 38 gêneros, sendo 40 destas espécies comuns, uma endêmica do Estado do Espírito Santo e 19 endêmicas do Brasil. Em relação à medida de conservação, quatro espécies estão presentes na categoria Dados Insuficientes (DD), uma presente na categoria Quase Ameaçada (NT), três espécies na categoria Vulnerável (VU) e uma na categoria Em Perigo (EN). Foram consideradas 25 espécies como novas ocorrências para a cidade. Estes resultados sugerem que a fauna da região estudada merece atenção e apontam o interesse em implantar futuras unidades de conservação na região do Município de Santa Teresa.

Palavras-chave: Anisoptera; Odonata; Zygoptera; Riqueza; Conservação.

\section{Introduction}

The Atlantic Forest is one of the most important regions for world's biodiversity conservation, thanks to a combination of high species richness and endemism, combined with the advanced state of degradation. According to data from the Fundação SOS Mata Atlântica (SOS Atlantic Forest Foundation) and Instituto Nacional de Pesquisas Espaciais (INPE - National Institute of Spacial Research), in 2008, well preserved (over $100 \mathrm{ha}$ ) forest fragments totalled 7,91\% of the original area of the Atlantic Forest - showing up a point of priority for conservation of the biodiversity (Myers et al., 2000; Mittermeier et al., 2004).

One of the biggest obstacles for conservation is the lack of information (knowledge of the distribution and abundance of species) that allow the implementation of efforts and priorities in management practices (Pimm et al., 2001). Many parameters are used as criteria for the selection of areas of priority for conservation, such as species richness, endemism, threatened state, taxonomic singularities and environmental representability (Prendergast et al., 1999). Nowadays, few biological groups have well represented data bases, causing priority areas for conservation to be selected based mostly - if not solely on data of mammals, birds and, more scarcely, reptiles and amphibians (e.g.
MMA, 2002). However, there are studies showing that areas with bigger richness and endemism fora group do not necessarily coincide with high richness and endemism for other groups that are intent on being preserved as well (Prendergast et al., 1993).

Despite the big representation as part of the biodiversity and the undeniable role in the functioning of the tropical ecosystems, insects are not frequently used in the determination of priority areas for conservation, specially in Brazil, because of the lack of systematized information (De Marco and Coelho, 2004). Most arthropods seem not to cause interest in conservation studies, making them general neglected by the management plan's creators. Such reality should be different, considering how easy it is to sample animals from this group (Merret and Snazel, 1983) and how efficient they are as ecological bioindicators (Wise, 1993), what makes them very useful for management politics. The conservation status of Brazilian invertebrates was summarized in lists of species threatened both in a national level (MMA, 2003; MMA, 2014) as well as a state/regional level (e.g. Passamani and Mendes, 2007). The biggest utility of these lists has been in the planning of the landscapes, in the monitoring and in the conservation of whole ecosystems (Casagrande et al., 
1998; Machado, 1998; Bergallo et al., 2000).

The Odonata Order (also known as dragonflies and damselflies) comprises 5.827 species (Garrison and Von Ellenrieder, 2016) and has three suborders: Anisoptera, Zygoptera and Anisozygoptera (Corbet, 1952 and 1999; Davies, 1981; May, 1991), though only the first two occur in Brazil, where there are 851 registered species, divided in 145 genera (Pinto, 2017). The adult members generally settle in the vicinity of fresh water, although some can be seen far from it. The immature state (larvae) are aquatic and can be found potentially in all fresh water environments (Corbet, 1999). Because of their dependence on water, the odonata are heavily affected by its physical and chemical condition, which enables them to be used as bioindicators of water quality for lakes and streams (Castella, 1987; Gorham and Vodopich, 1992; Peruquetti and De Marco, 2002). Additionally, both larvae and adults are dependent on the matrix of characteristics of the surrounding environment, making them good indicators of environmental changes in a variety of parameters (Peruquetti and De Marco, 2002).

The main goal of this study was to do a survey of the species of Odonata occurring in the Santa Teresa Municipality, in the Brazilian State of Espírito Santo, as well as to determine the occurrence of threatened and endemic species and determine, through their biological data, their potential for use as bioindicator. Therefore, expanding the knowledge of the order for Santa Teresa Municipality and the Atlantic Forest as a whole too. The knowledge of the regional faunas is important to provide numerical data that are more representative of the reality for the species and their composition.

\section{Material and methods}

\section{Study area}

The survey was done for the municipality of Santa Teresa, located at $650 \mathrm{~m}$ above sea level in meso-central area of the State of Espírito Santo. Santa Teresa has a total area of 71.110 ha and is located in the Atlantic Forest Region, considered to have the biggest biodiversity of plants on Earth (Mendes and Padovan, 2000); $40 \%$ of its area is covered by preserved areas of Atlantic Forest (Thomaz and Monteiro, 1997). The hidrography of the Santa Teresa Municipality is composed of many streams, most important of all being the Timbuí River, composed by the junction of the São Pedro and São Lourenço Streams. The Timbuí River is in a critic state in regards to the quality of the water, and has an old history of pollution (Louzada and Fonseca 2002).

\section{Database construction}

A database was constructed with the inclusion of the known species of Odonata for the Santa Teresa Municipality, based on previous information and an already existing database, developed by the group: Ecology, Evolution and Conservation of Odonata, which is lead by Dr. Paulo de Marco (Laboratory of Theory, Metacommunity and Ecology of Landscapes, Federal University of Goias) and includes data from the literature and zoological collections.

During the update of the database, the first step was a visit to the Coleção Zoológica Norte Capixaba/CZNC (Zoological Collection of the Northern Espírito Santo, CEUNES/UFES) in search of specimens registered for Santa Teresa, with their posterior identification and inclusion in the collection's entry book. Later, a search was done in specialized site (such as Scielo) for published papers 
between 1960 and 2016 that included Odonata registered for Santa Teresa. Finally, a visit to the local faculty of Santa Teresa (Escola Superior São Francisco de Assis - ESFA), where was found a nonpublished monograph (Buss et al., unpublished data) and many related specimens deposited in the collection of the Museu de Biologia Professor Mello Leitão (Mello Leitão Museum). All obtained data was revised by Dr. Karina Furieri, group specialist and researcher participant during the mentioned monograph's work.

The data base includes the following information: species name; family; locality (municipality and state); sampling point (e.g. name of the farm or lake, if possible); latitude and longitude; additional observation (such as type of vegetation). The species were identified utilizing identification Keys for the group (Garrizon et al., 2006 and 2010; Lencioni, 2005 and 2006) and comparisons with specimens previously identified by specialists. Dubious specimens and females were not included and can be posteriorly added to the Data Base. The species registered for Santa Teresa were classified as commons, endemic for the Espírito Santo, endemic for Brazil, rare and/or threatened by extinction, at a state (Simonelli, 2007) and national level (MMA, 2014).

\section{Record of biological aspects of the catalogued species}

After the construction of the updated Data Base, a research was done about each recorded species. In addition to bibliography, description sheets developed by the group for evaluation of conservation state of Odonata from Brazil (ICMBio and specialists on Odonata) were used - this data being provided by Dr. Karina Furieri. Some species were not described due to lack of information.

\section{Elaboration of the map \\ By using the program QGIS} version 2.14.3 (GRASS version 7.0.4), a map was generated with the distribution of all the species recorded in the Data Base, in which is present all the forest remains in the Santa Teresa Municipality, as well as other areas of occurrence of species (as long as they present coordinates).

\section{Results}

A total of 77 species was registered, distributed in eight families and 38 genera (Table 1). The family with the biggest richness was Coenagrionidae with 32 species, followed by Libellulidae with 27. The families Aeshnidae, Calopterygidae, Heteragrionidae, Lestidae and Megapodagrionidae presented two, six, six, three and one species, respectively.

Twenty-five species were considered new occurrences for the municipality and were included in the Data Base. They are kept at the Coleção Zoológica Norte Capixaba/CZNC (Zoological Collection of the North of the Espírito Santo).

One species was considered endemic for the state of Espírito Santo (Leptagrion capixabae) and twenty-two were considered endemic for Brazil (Table 1). In relation to the degree of conservation in Espírito Santo (Passamani and Mendes, 2007), Leptagrion capixabae Santos, 1965, is considered Critically Endangered - CR. In relation to the degree of conservation in Brazil (MMA, 2014 and the research sheets from the ICMBio group), one species is considered Endangered - EN (Heteragrion petiense Williamson, 1909), two species are in the category Vulnerable - VU (Aceratobasis cornicauda (Calvert, 1909) and Leptagrion capixabae), one species is in the category Near Threatened - NT (Leptagrion dispar Selys, 1876), three species are in the category Data Deficient - DD (Forcepsioneura lucia Machado, 2000, Minagrion canaanense Santos, 1967 and Micrathyria ocellata Martin, 1897) and 
60 species are in the category Least Concerned - LC (Table 1).

A total of 627 dragonflies were accounted in the Data Base for Santa Teresa. Two hundred and sixty of those specimens were already inserted in the Data Base by Dr. Paulo de Marco Jr and the remaining records were obtained at the Coleção Zoológica Norte Capixaba/ CZNC (Zoological Collection of the North of the Espírito Santo), the Museu de Biologia Professor Mello Leitão (Biological Museum Professor Mello Leitão) and at recent unpublished works.

Table 1. Families and species of Odonata registered for the municipality of Santa Teresa (Espírito Santo, Brazil) with the respective categories of conservation, according to the Brazilian Red List.

\begin{tabular}{|c|c|c|c|}
\hline Family & Species & $\begin{array}{c}\text { IUCN } \\
\text { category }\end{array}$ & Locality \\
\hline Aeshnidae & Coryphaeschna amazonica De Marmels, 1989 & $\mathrm{LC}$ & 10 \\
\hline Aeshnidae & Triacanthagyna septima (Selys in Sagra, 1857) & $\mathrm{LC}$ & 11 \\
\hline Gomphidae & Aphylla theodorina (Náveas, 1933) & $\mathrm{LC}$ & 21 \\
\hline Libellulidae & Brechmorhoga praedatrix Calvert, 1909* & $\mathrm{LC}$ & 17 \\
\hline Libellulidae & Dasythemis mincki (Karsch, 1890)* & $\mathrm{LC}$ & 17 \\
\hline Libellulidae & Diastatops obscura (Fabricius, 1775) & $\mathrm{LC}$ & 5,11 \\
\hline Libellulidae & Elasmothemis cannacrioides (Calvert, 1906)* & $\mathrm{LC}$ & 5 \\
\hline Libellulidae & Erythrodiplax clitella Borror, 1942 & $\mathrm{LC}$ & 10 \\
\hline Libellulidae & Erythrodiplax fusca (Rambur, 1842) & $\mathrm{LC}$ & 10 \\
\hline Libellulidae & Erythrodiplax juliana Ris, 1911 & $\mathrm{LC}$ & 10 \\
\hline Libellulidae & Macrothemis rupicola Rácenis, 1957* & $\mathrm{LC}$ & 5,17 \\
\hline Libellulidae & Micrathyria artemis Ris, 1911 & $\mathrm{LC}$ & $5,11,17$ \\
\hline Libellulidae & Micrathyria atra (Martin, 1897) & $\mathrm{LC}$ & 10 \\
\hline Libellulidae & Micrathyria catenata Calvert, 1909 & $\mathrm{LC}$ & 11 \\
\hline Libellulidae & Micrathyria hesperis Ris, 1911 & $\mathrm{LC}$ & 11 \\
\hline Libellulidae & Micrathyria hypodidyma Calvert, 1906 & $\mathrm{LC}$ & $5,11,17$ \\
\hline Libellulidae & Micrathyria ocellata Martin, 1897* & DD & 5 \\
\hline Libellulidae & Micrathyria pirassunungae Santos, 1953 & $\mathrm{LC}$ & 17 \\
\hline Libellulidae & Micrathyria stawiarskii Santos, 1953 & $\mathrm{LC}$ & $5,11,17$ \\
\hline
\end{tabular}


Table 1. Continued.

\begin{tabular}{|c|c|c|c|}
\hline Family & Species & $\begin{array}{c}\text { IUCN } \\
\text { category }\end{array}$ & Locality \\
\hline Libellulidae & Nephepeltia phryne (Perty, 1834) & $\mathrm{LC}$ & 10 \\
\hline Libellulidae & Oligoclada abbreviata (Rambur, 1842) & $\mathrm{LC}$ & 11 \\
\hline Libellulidae & Orthemis ambinigra Calvert, 1909 & $\mathrm{LC}$ & 5,17 \\
\hline Libellulidae & Pantala flavescens (Fabricius, 1798) & $\mathrm{LC}$ & 10 \\
\hline Libellulidae & Perithemis lais (Perty, 1834)* & $\mathrm{LC}$ & 5 \\
\hline Libellulidae & Perithemis mooma Kirby, 1889* & $\mathrm{LC}$ & $5,10,17$ \\
\hline Libellulidae & Tauriphila argo (Hagen, 1869) & $\mathrm{LC}$ & 10 \\
\hline Libellulidae & Tramea abdominalis (Rambur, 1842) & $\mathrm{LC}$ & 10 \\
\hline Libellulidae & Tramea binotata (Rambur, 1842) & $\mathrm{LC}$ & 10 \\
\hline Libellulidae & Zenithoptera anceps Pujol-Luz, 1993 & $\mathrm{LC}$ & 11 \\
\hline Calopterygidae & Hetaerina auripennis (Burmeister, 1839) & $\mathrm{LC}$ & $\begin{array}{c}1,2,3,4,5 \\
10,16,17 \\
20\end{array}$ \\
\hline Calopterygidae & Hetaerina brightwelli (Kirby, 1823)* & $\mathrm{LC}$ & 5,17 \\
\hline Calopterygidae & Hetaerina longipes Hagen in Selys, $1853^{*}$ & $\mathrm{LC}$ & 11 \\
\hline Calopterygidae & Hetaerina proxima Selys, $1853^{*}$ & $\mathrm{LC}$ & 20 \\
\hline Calopterygidae & Hetaerina rosea Selys, 1853 & $\mathrm{LC}$ & $\begin{array}{c}2,5,13 \\
15,16,17 \\
18,21\end{array}$ \\
\hline Calopterygidae & Hetaerina simplex Selys, 1853 & $\mathrm{LC}$ & 2 \\
\hline Coenagrionidae & Acanthagrion cuyabae Calvert, 1909* & $\mathrm{LC}$ & 5 \\
\hline Coenagrionidae & Acanthagrion gracile Rambur, 1842 & $\mathrm{LC}$ & $\begin{array}{c}1,4,5,7,8 \\
9,13,14 \\
15,17,18\end{array}$ \\
\hline Coenagrionidae & Acanthagrion lancea Selys, 1876 & $\mathrm{LC}$ & $\begin{array}{c}1,5,7,13 \\
15,17\end{array}$ \\
\hline Coenagrionidae & Aceratobasis cornicauda (Calvert, 1909) & VU & 11 \\
\hline Coenagrionidae & Argia modesta Selys, $1865^{*}$ & $\mathrm{LC}$ & 5,20 \\
\hline Coenagrionidae & Argia sordida Hagen in Selys, $1865^{*}$ & $\mathrm{LC}$ & 5,17 \\
\hline Coenagrionidae & Enallagma novaehispaniae Calvert, 1907* & $\mathrm{LC}$ & 5,17 \\
\hline
\end{tabular}


Table 1. Continued.

\begin{tabular}{|c|c|c|c|}
\hline Family & Species & $\begin{array}{c}\text { IUCN } \\
\text { category }\end{array}$ & Locality \\
\hline Coenagrionidae & Forcepsioneura lucia Machado, 2000 & DD & 17 \\
\hline Coenagrionidae & Homeoura chelifera (Selys, 1876) & $\mathrm{LC}$ & $\begin{array}{c}5,11,12 \\
13,14,15 \\
17\end{array}$ \\
\hline Coenagrionidae & Ischnura capreolus (Hagen, 1861) & $\mathrm{LC}$ & $5,8,9,10$ \\
\hline Coenagrionidae & Ischnura fluviatilis Selys, $1876^{*}$ & $\mathrm{LC}$ & 5 \\
\hline Coenagrionidae & Leptagrion capixabae Santos, 1965 & VU & $55,11,17$ \\
\hline Coenagrionidae & Leptagrion dispar Selys, 1876 & NT & $55,10,17$ \\
\hline Coenagrionidae & Leptagrion macrurum (Burmeister, 1839) & $\mathrm{LC}$ & $55,11,17$ \\
\hline Coenagrionidae & Leptagrion perlongum Calvert, 1909 & $\mathrm{LC}$ & $55,11,17$ \\
\hline Coenagrionidae & Mecistogaster amalia (Burmeister, 1839)* & $\mathrm{LC}$ & 5,17 \\
\hline Coenagrionidae & Metaleptobasis selysi Santos, 1956 & $\mathrm{LC}$ & 17 \\
\hline Coenagrionidae & Minagrion canaanense Santos, 1967 & DD & $55,11,17$ \\
\hline Coenagrionidae & Neoneura ethela Williamson, $1917^{*}$ & $\mathrm{LC}$ & 5,17 \\
\hline Coenagrionidae & Neoneura sylvatica Hagen in Selys, 1886* & $\mathrm{LC}$ & 5 \\
\hline Coenagrionidae & Oxyagrion basale Selys, 1876 & $\mathrm{LC}$ & 11,17 \\
\hline Coenagrionidae & Oxyagrion evanescens Selys, 1876 & $\mathrm{LC}$ & $1,11,18$ \\
\hline Coenagrionidae & Oxyagrion hempeli Calvert, 1909 & $\mathrm{LC}$ & 11 \\
\hline Coenagrionidae & Oxyagrion pavidum Hagen in Selys, 1876 & $\mathrm{LC}$ & $\begin{array}{c}5,11,17 \\
21\end{array}$ \\
\hline Coenagrionidae & Oxyagrion santosi Martins, 1967 & $\mathrm{LC}$ & 8,9 \\
\hline Coenagrionidae & Oxyagrion simile Costa, 1978 & $\mathrm{LC}$ & $\begin{array}{c}7,8,9,11 \\
15,18\end{array}$ \\
\hline Coenagrionidae & Peristicta aeneoviridis Calvert, 1909 & $\mathrm{LC}$ & 5 \\
\hline Coenagrionidae & Peristicta jalmosi Pessacq \& Costa, 2007* & $\mathrm{LC}$ & 11,5 \\
\hline Coenagrionidae & Telagrion longum Selys, $1875^{*}$ & $\mathrm{LC}$ & 17 \\
\hline Coenagrionidae & Telebasis corallina (Selys, 1876) & $\mathrm{LC}$ & $\begin{array}{c}5,7,8,9 \\
13\end{array}$ \\
\hline Coenagrionidae & Telebasis filiola (Perty, 1834) & LC & $4,5,8$ \\
\hline
\end{tabular}


Table 1. Continued.

\begin{tabular}{|l|l|c|c|}
\hline Family & \multicolumn{1}{|c|}{ Species } & $\begin{array}{c}\text { IUCN } \\
\text { category }\end{array}$ & Locality \\
\hline Coenagrionidae & Tigriagrion aurantinigrum Calvert, 1909 & LC & 5,17 \\
\hline Heteragrionidae & Heteragrion aurantiacum Selys, 1862 & LC & $\begin{array}{c}1,2,3,4,5, \\
11,17\end{array}$ \\
\hline Heteragrionidae & Heteragrion consors Hagen in Selys, 1862* & LC & 5,17 \\
\hline Heteragrionidae & Heteragrion dorsale Selys, 1862* & LC & 5 \\
\hline Heteragrionidae & Heteragrion flavovihatam Selys, 1862 & LC & 12 \\
\hline Heteragrionidae & Heteragrion petiense Williamson, 1909 & EN & $6,19,21$ \\
\hline Heteragrionidae & Heteragrion triangulare Calvert, 1901* & LC & 11 \\
\hline Lestidae & Lestes forficula Rambur, 1842 & LC & 19 \\
\hline Lestidae & Lestes pictus Hagen in Selys, 1862 & LC & 9 \\
\hline Lestidae & Lestes tricolor Erichson in Schomburgk, 1848* & LC & 5,17 \\
\hline Megapodagrionidae & Allopodagrion contortum (Hagen in Selys, 1862) & 1,11 \\
\hline
\end{tabular}

The categories are: LC - least concerned, DD - deficient data, NT - near threatened, , VU - vulnerable, EN - endangered. The sample localities are as follows: 1, 2, 3 and 4 - São Pedro stream, 5 - Santa Lucia Biological Station, 6 - Santa Lucia Spring, 7 and 8 - Santo Antônio Spring, 9 - São Pedro Spring, 10 - Paradiso Inn, 11 and 12 - Biological Reserve Augusto Ruschi, 13, 14, 15, 16, 17, 18 and 19 Timbuí River, 20 - São Lourenço, 21 - Vargem Alta. The light grey lines represent species endemic to Brazil and the dark grey line the species endemic to Espírito Santo. The * indicates a new occurrence.

\section{Biological aspects of the species Aceratobasis cornicauda} (Calvert, 1909)

Adults of this genus fly slowly in areas shadowed by secondary forests, by short distances, until roosting (Lencioni, 2005). Behaviour, habitat of reproduction and larvae are unknown (Von Ellenrieder, 2008), though with indications that this species uses Bromeliads for larval development (Lencioni, 2006). This is a forest species and has low populational density (Garrison et al., 2010).

\section{Forcepsioneura lucia Machado,} 2000

Forcepsioneura lucia is a forest species. Usually roosts on small branches close to the humid floor of the forest. This species is not found close to the river and it is possible its larvae lives in the humid litter of the forest instead of in the bodies of water. Normally are found near lentic parts of the stream (Machado, 2000).

$\begin{array}{ll} & \text { Heteragrion aurantiacum } \\ \text { Selys, 1862; Heteragrion consors } \\ \text { Hagen in Selys, 1862; Heteragrion }\end{array}$


dorsale Selys, 1862; Heteragrion flavovihatam Selys, 1862; Heteragrion petiense Williamson, 1909 and Heteragrion triangulare Calvert, 1901 Heteragrion is a forest genus found exclusively in wood streams where its larvae lives. It is very susceptible to environmental changes (Monteiro-Junior et al., 2014). Some genera are indicators of environmental quality, like Heteragrion, which is not found in deforested or polluted places (MonteiroJunior et al., 2014). Heteragrion aurantiacum occurs in areas with small changes (Peruquetti and De Marco, 2002). Oliveira (2013) found the species to be well represented and highly abundant at well preserved streams and Peruquetti and De Marco (2002) found Heteragrion aurantiacum only in areas with well-preserved riparian vegetation. Heteragrion petiense was always found roosting on marginal vegetation of small streams with nearly still water, where its larvae probably live, in the depths of preserved woods (Machado, 1998; Machado, 2008).

Leptagrion capixabae Santos, 1965; Leptagrion dispar Selys, 1876; Leptagrion macrurum (Burmeister, 1839) and Leptagrion perlongum Calvert, 1909

The larvae of the genus Leptagrion develops in the water accumulated on bromeliads (Furieri, 2004). Santos (1966) estimated the development time for four species of the genus as being between six and twelve months. The dependence on preserved habitats with bromeliads makes Leptagrion a bioindicator species, even more those threatened of extinction. The distribution of Leptagrion capixabae includes areas with rocky outbursts that are usually colonized by bromeliads of the genus Alcantarea, which could be the preferred habitat for L. capixabae. Adult males were observed roosting on big bromeliads of the species Alcantarea extensa in the Municipality of Ibiraçu and data suggests that this species has a resident behaviour and prefers bromeliads of rocky areas as their reproductive site (Furieri, 2004). The biggest threats to this species are the changes to its habitat by means of deforestation, rock extractions and forest fires (ICMBio research sheets). Leptagrion dispar has been observed, most of the time, in sunny areas and roosting on bromeliads of bigger size, like Aechmea blanchetiana (Furieri, 2004).

Micrathyria artemis Ris, 1911, Micrathyria atra (Martin, 1897), Micrathyria catenata Calvert, 1909, Micrathyria hesperis Ris, 1911, Micrathyria hypodidyma Calvert, 1906, Micrathyria ocellata Martin, 1897, Micrathyria pirassunungae Santos, 1953, and Micrathyria stawiarskii Santos, 1953

The genus Micrathyria habits lakes and streams, including temporary and saline (Garrison et al., 2006). Consatti (2014) found Micrathyria ocellata only in poorly preserved areas, though this is the only record for this preference. Peruquetti (2002) found Micrathyria pirassunungae happening only in areas of monoculture, though for this case as well, no other report has been found to confirm the preference.

\section{Map with the points of occurrence for the species}

The localities sampled in Santa Teresa are: São Pedro Stream, Santa Lucia Biological Station, Santa Lucia Spring, Santo Antônio Spring, São Pedro Spring, Paradiso Inn, Biological Reserve Augusto Ruschi, Timbuí River, São Lourenço and Vargem Alta (Figura 2).

The São Pedro Stream is an affluent to the Timbuí River and is surrounded by woods, pasture and agricultural areas. The São Pedro Stream point 1 is a lotic environment of dirty water, the point 2 is a lotic environment of clean water, the point 3 is a lotic environment surrounded by woods and the point 4 is lotic environment of dirty 
water. The spring of the São Pedro Stream is disturbed and altered, and is a lentic environment with riparian vegetation on one side and pasture on the other (Buss et al., unpublished data).

The Santa Lucia Biological Station (Estação Biológica Santa Lúcia, EBSL), that includes other points, is managed by the Museu Biologia Professor Mello Leitão (MBML) and, besides being a preservation area, is not included in the National System of Preservation Areas, nor is under any particular category of protection. The vegetation of the EBSL is in advanced stages of succession, with indications of anthropic disturbances localized in areas of old agricultural use (Mendes and Padovan, 2000). The Santa Lucia Spring is located inside the EBSL, is characterized as a lentic environment of woods (Buss et al., unpublished data). The Santo Antônio Spring is a lentic environment in the woods (Buss et al., unpublished data).
The Timbuí River, that includes most of the coordinates of occurrences of Odonata for the Santa Teresa Municipality, runs through the urban perimeter and receives the domestic wastes and other effluents, being one of the main hydric resources of Santa Teresa (Mauri et al., 2007). The physical and chemical parameters show that the Timbuí River is very polluted, presenting low concentration of solved oxygen and high turbidity (Mauri et al., 2007). The point 13 consists of a lentic environment in the woods; the point 14 is a lotic environment with riparian vegetation on one side and pasture on the other; the point 15 is a lotic environment in the woods; the point 16 is a lotic environment with riparian vegetation on one side and pasture on the other; the point 17 is a lotic environment surrounded by pasture and the point 18 is a well preserved environment of clean stream (Buss et al., unpublished data).

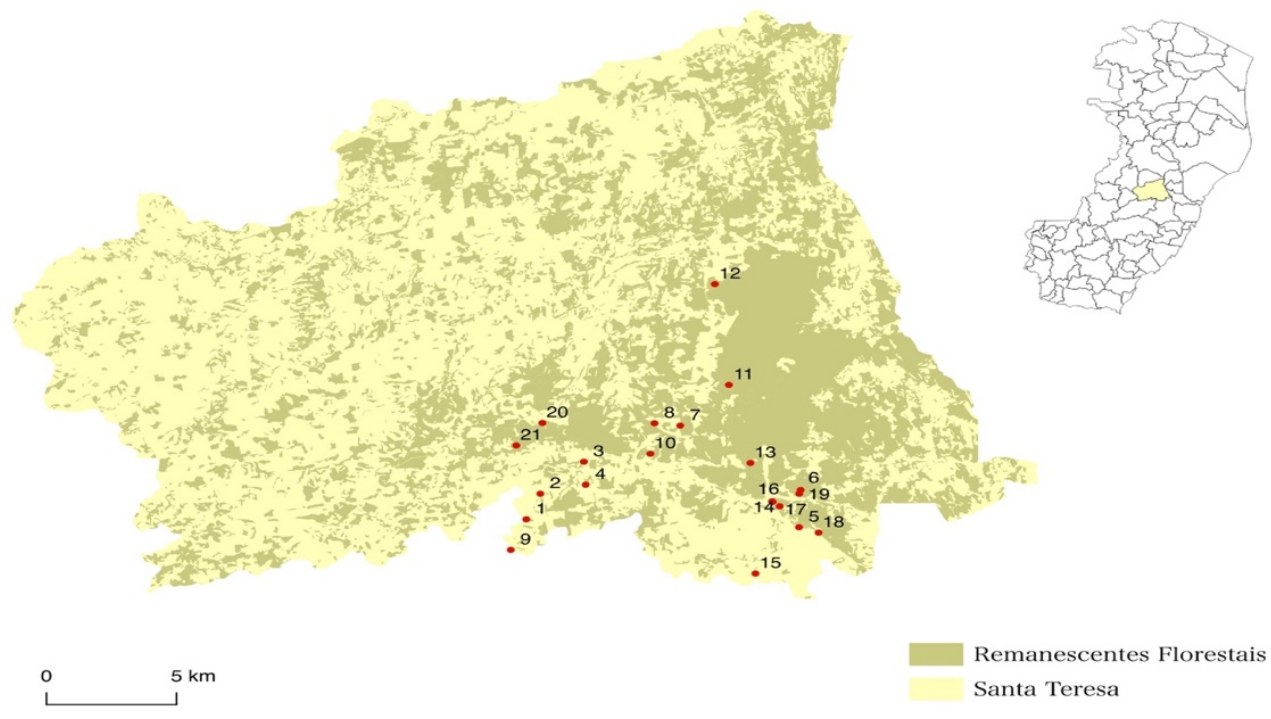

Figure 1. Map of the forest remnants and sampling localities for Odonata in the Santa Teresa Municipality, Espírito Santo. Points 1, 2, 3, and 4 - São Pedro stream, 5 - Santa Lucia Biological Station, 6 - Santa Lucia spring, 7 and 8 - Santo Antônio spring, 9 - São Pedro spring, 10 - Paradiso Inn, 11 and 12 - Augusto Ruschi Biological Reserve, 13, 14, 15, 16, 17, 18 and 19 - Timbuí River, 20 São Lourenço, 21 - Vargem Alta. 
Table 2. Coordinates of the occurrences of Odonata species in Santa Teresa, Espírito Santo.

\begin{tabular}{|l|c|c|}
\hline Point & Latitude & Longitude \\
\hline 1 - São Pedro stream & -19.960833 & -40.640556 \\
\hline 2 - São Pedro stream & -19.949444 & -40.635278 \\
\hline - São Pedro stream & -19.935278 & -40.619167 \\
\hline 4 - São Pedro stream & -19.945556 & -40.618611 \\
\hline 5 - Santa Lúcia Biological Station & -19.965254 & -40.540487 \\
\hline 6 - Santa Lúcia spring & -19.948611 & -40.539722 \\
\hline 7 - Santo Antônio spring & -19.919444 & -40.583611 \\
\hline 8 - Santo Antônio spring & -19.918333 & -40.593056 \\
\hline - São Pedro spring & -19.974444 & -40.646389 \\
\hline 10 - Paradiso Inn & -19.931944 & -40.594722 \\
\hline 11 - Augusto Ruschi Biological Reserve & -19.901400 & -40.565600 \\
\hline 12 - Augusto Ruschi Biological Reserve & -19.856300 & -40.570300 \\
\hline 13 - Timbuí River & -19.936389 & -40.558056 \\
\hline 14 - Timbuí River & -19.953889 & -40.550000 \\
\hline 15 - Timbuí River & -19.985833 & -40.556667 \\
\hline 16 - Timbuí River & -19.953611 & -40.550278 \\
\hline 17 - Timbuí River & -19.955833 & -40.547500 \\
\hline 18 - Timbuí River & -19.967778 & -40.533333 \\
\hline 19 - Timbuí River & -19.950278 & -40.540278 \\
\hline 20 - São Lourenço & -19.917778 & -40.634167 \\
\hline 21 - Vargem Alta & -19.927778 & -40.643889 \\
\hline
\end{tabular}

\section{Discussion}

The protected areas in Santa Teresa are of big biological importance because of their high diversity of plants and their role as ecological corridors (IPEMA, 2005). The Municipality of Santa Teresa is considered an Atlantic Forest sanctuary in the Espírito Santo State, possessing some of the most species rich environment on the planet: the Estação Biológica de Santa Lúcia and the Reserva Biológica Augusto Ruschi (Mauri et al., 2007). Santa Teresa still conserver 35\% of its territory covered by Atlantic Forest vegetation, making it an important area of remnant for this biome (IPES, 2016).

Compared with the Odonata diversity of the Espírito Santo State (224 species, 73 genera and 11 families - Cruz, unpublished data), Santa Teresa show a big representation, with $35 \%$ of the species, $52 \%$ of the genera and $73 \%$ of the families recorded for the state. The data from CZNC added 25 new occurrences, highlighting the importance of identifying the specimens kept in zoological collections. It is important to give priority to the information of specimens already deposited in collections and to spread that data in the form of papers or data bases.

Zygoptera is a group of insects that normally is associated to more preserved places with riparian vegetation, because of its more restricted biological needs (Corbet, 1999). The bigger richness of Zygoptera in Santa Teresa Municipality can reflect the large (35\%) portion of the territory still covered by Atlantic Forest vegetation (relatively preserved places), showing that the local systems might be in an equilibrium.

The vegetation in the Estação Biológica Santa Lúcia is in advanced stages of succession (Mendes and Padovan, 2000). Despite its relatively big forest cover, Santa Teresa suffers the impact of domestic wastes, garbage accumulation and other types of residue that are deposited in the Timbuí River. The Timbuí River and the other streams that run through the city are known as 
'sewers', mainly because $90 \%$ of the residences uses them as recipient of their wastes, which brings consequences like turning these streams into producers of vectors (Mendes and Padovan, 2000).

The bigger representation of Zygoptera in Santa Teresa might be explained as well by bigger sampling effort in relation to this group, justified for example by the bigger number of specialists on this group and its genera, like the specimens found in the CZNC, mostly having been collected by Dr. Karina Furieri, researcher who works mainly with the Zygoptera Suborder.

The endemic species, as well as those with bigger area requirements, answer more quickly to the habitat fragmentation dynamics, therefore making up a significative number of the threatened taxa that need to be protected (Grelle et al., 1999; Paglia, 2005). The presence of endemic species is, then, considered an important factor to point the environmental representation of a place. Leptagrion capixabae must be highlighted for its status as a rare species, endemic to the Espírito Santo State, and its recent rediscovery with few known populations (Furieri et al., 2004). The species is also in the Critically Endangered (CR) category according to the state Red List and Vulnerable (VU) according to the national Red List. The specialization on phytotelma microhabitat can leave the species exposed to habitat destruction, be it by deforestation or illegal extraction of bromeliads for use as ornaments (Simonelli and Fraga 2007). Other than $L$. capixabae, L. dispar, L. macrurum and $L$. perlongum occur in Santa Teresa as well. It's important to observe that other species of Leptagrion were not included in the list of threatened species, despite their rarity in collections, due to the lack of information even about their points of occurrence. This set of species is probably under threat of extinction, mainly because of habitat loss.

Other species in the region must also be highlighted, like Heteragrion petiense, inserted in the category Endangered - EN (MMA, 2014), which is a species with restricted distribution (Machado, 1998); it's population has been considered severely fragmented due to the intensity of habitat loss (converted to agriculture) added to its need of streams with well-preserved woods, causing a decline in its areas of occurrence (ICMBio research sheets).

Another Vulnerable (VU) species - Acerotobasis cornicauda, is also in this category because of the limited area of occurrence and its growing occupation and alteration by human activities (agriculture and urbanization), resulting in a continuous fragmentation and severe loss of habitat quality and extension, representing a direct threat to the populations (ICMBio research sheets).

A species in the Nearly Threatened (NT) category, Leptagrion díspar, deserves attention for its preference for areas of restinga (sandbank vegetation), specially points with higher rates of Sunshine on the bromeliads; its habitat is severely altered (deforested, fragmented, under urban influence, receiving wastes and under illegal exploitation of sand and bromeliads), with continued decline of vegetation (ICMBio research sheets). Considering that Brazil has recognized 18 dragonfly species threatened by extinction, the presence of three of them in a single municipality makes it very relevant to preserve the diversity of the group.

Other than the threatened species, it is also important to consider the three species in the Data Deficient (DD) category (Forcepsioneura lucia, Minagrion canaanense and Micrathyria ocellata), showing the need to expand the knowledge of these taxa.

The places of occurrence to be highlighted are: Estação Biológica de Santa Lúcia, that presented the species Leptagrion capixabae (VU), Leptagrion dispar (NT) and Minagrion canaanense (DD); Santa Lúcia Spring, with 
occurrences of Heteragrion petiense (EN); Reserva Biológica Augusto Ruschi, with occurences of Aceratobasis cornicauda (VU), Leptagrion capixabae and Minagrion canaanense (DD); the point 18 of the Timbuí River, where occur Forcepsioneura lucia (DD), Leptagrion capixabae, Leptagrion dispar (NT) and Minagrion canaanense (DD); and São Lourenço, where occurs Heteragrion petiense (EN). These points are considered important for the conservation of the Atlantic Forest fauna, specially the Odonata of the Espírito Santo State.

The information about the biology of most of the species registered for the Santa Teresa Municipality is still scarce, limiting the discussion about their individual potential as bioindicators. Even so, 13 species of the Data Base have been considered as presenting use as indicators of high environmental quality (Argia modesta, Argia sordida, Hetaerina brightwelli, Heteragrion aurantiacum, Heteragrion consors, Heteragrion dorsale, Heteragrion flavovihatam, Heteragrion petiense, Heteragrion triangulare, Leptagrion capixabae, Leptagrion dispar, Leptagrion macrurum and Leptagrion perlongum), and five species have been considered as indicator of impacted habitats (Hetaerina auripennis, Hetaerina longipes, Hetaerina proxima, Hetaerina rosea and Hetaerina simplex), based on the revised works. The preference of the Odonata species for habitats in Brazil is still poorly known, and determining the reason behind the preferences for impacted habitats by certain genera is important to their utilization in works monitoring the quality of aquatic systems (Fore et al., 1996). However, Hetaerina brightwelli is an indicator of a well-preserved habitat, on the opposite of the other species in the genus, further demonstrating the need to study each species individually and the difficulty of expanding the patterns of a species to a whole genus for use as bioindicators.
It is possible that rare species occur in Santa Teresa and have yet to be registered. Observing the map with the registered species for the municipality and the published studies, it is perceptible that a big area has not yet been sampled, and most of the registered species came from the Timbuí River and the Estação Biológica Santa Lúcia. The municipality includes three basins: Três Magos River Basin (with two river arms: the Fundão River and the Timbuí River the latter being most important source of water the Santa Teresa municipality), the Piraquê-açu river and the Santa Maria do Rio Doce River (Mendes and Padovan, 2000). The sampling in not yet studied points is needed to complete the knowledge about the fauna of Odonata in Santa Teresa. Species distribution modelling can be used to predict new areas of occurrence for rare and threatened species (e.g. Engler et al., 2004; Guisan et al., 2006; Gibson et al., 2007).

\section{Conclusion}

The species richness found, the presence of populations of threatened species and the inclusion of newly registered species for Santa Teresa suggests that the fauna of the region deserves more attention and points to the benefits of creating new conservation units. New samples in the region are needed, especially in the northern and western sides of the municipality, where the register of occurrences is virtually inexistent. The affluents of the Piraquê-Açu and the Santa Maria do Rio Doce Basin are highlighted as important points for future samples, in order to better represent the Odonata diversity of Santa Teresa. It is also needed the study of the Data Deficient (DD) species.

The future of the conservation of invertebrates depends on the preservation of habitats as a whole and on a more complete comprehension of the roles on maintaining ecosystem's processes. The potential of the 
conservation units in Santa Teresa is dependent not only on their integrity but also on a program of conservation of the Atlantic Forest in a regional scale. Since most of the forest remnants of the region are under private ownership, a system that encourages their maintenance is needed, such as the recommendation to create private conservation units.

\section{Acknowledgments}

I would like to thank Dr. Frederico for allowing us to use the physical space of his laboratory during the research. Special thanks to Dr. Paulo De Marco, who greatly provided incredible data, wich was crucial for the realization of such study.

\section{Conflicts of interest}

Authors declare that they have no conflict of interests.

\section{References}

Bergallo, H. G.; Rocha, C. F. D.; Alves, M. A. S.; Van Sluys M. A fauna ameaçada de extinção do Estado do Rio de Janeiro. Rio de Janeiro: Ed. UERJ, 2000.

Buss, J. P. E.; Petter, K.; Martinelli, W. A. Levantamento de Odonata como bioindicadores de qualidade ambiental no município de Santa Teresa-ES. Santa Teresa: Escola Superior São Francisco de Assis (ESFA), 2014. (Monography).

Casagrande, M. M.; Mielke, O. H. H.; Brown, K. S. Borboletas (Lepidoptera) ameaçadas de extinção em Minas Gerais, Brasil. Revista Brasileira de Zoologia, v. 15, p. 241-259, 1998.

Castella, E. Larval Odonata distribution as a describer of fluvial ecosystems: the Rhône and Ain Rivers, France. Advances in Odonatology, v. 3, p. 23-40, 1987.

Consatti, G.; Santos, D. M.; Renner, S.; Périco, E. Presença de Odonata em áreas preservadas e não preservadas nas matas ciliares do Rio Taquari, RS. Revista de Iniciação Científica da ULBRA, n. 12, p. 57-65, 2014.
Corbet, P.S. An adult population study of Pyrhosoma nymphula (Sulzer): (Odonata: Coenagrionidae). Journal of Animal Ecology, v. 21, p. 206-222, 1952.

Corbet, P.S. Dragonflies: Behavior and Ecology of Odonata. Londres: Comstock Publishing Associates, 1999.

Costa, J. M.; Olbrini, B. B.; Souza, L. O. I. Chave para identificação das famílias e gêneros das larvas conhecidas de Odonata do Brasil: comentários e registros bibliográficos (Insecta, Odonata). Publicação Avulsas do Museu Nacional Rio de Janeiro, n. 99, p. 3-42, 2004.

Cruz, K. V. Diversidade e composição de Odonata (Insecta) dos Lagos do Baixo Rio e checklist para o Espírito Santo. São Mateus: Universidade Federal do Espírito Santo, 2016. (Master dissertation).

Davies, D. A. L. A synopsis of the extant genera of the Odonata. Society International of Odonatology Rapid Communication, v. 3, p. 1-59, 1981.

De Marco, P.; Coelho, F. M. Services performed by the ecosystem: Forest remnants influence agricultural cultures pollination and production. Biodiversity \& Conservation, v. 13 , no. 7 , p. $1245-1255$, 2004. https://doi.org/10.1023/B:BIOC.0000 019402.51193.e8

Efron, B. Bootstrap methods: Another look at the jackknife. In: Kotz S.; Johnson N. L. (Eds.). Breakthroughs in Statistics. New York: Springer, 1992. (Perspectives in Statistics). https://doi.org/10.1007/978-1-4612-43809_41

Engler, R.; Guisan, A.; Rechsteiner, L. An improved approach for predicting the distribution of rare and endangered species from occurrence and pseudo-absence data. Journal of Applied Ecology, v. 41, p. 263-274, 2004.

Fore, L. S.; Karr, J. R.; Wisseman, R. W. Assessing invertebrate responses to human activities: Evaluating alternative approaches. Journal of North American Benthological Society, v. 15, n. 2, p. 212-231, 1996.

Furieri, K. S.; Barreto, F. C. C.; De Marco, P. The rediscovery of Leptagrion capixabae Santos, 1965 (Odonata: Coenagrionidae). Notulae Odonatologica, v. 6, no. 3, p. 25-36, 2004. 
Garrison, R. W.; Von Ellerieder, N. A. Synonymic list of the New World Odonata: Revised version of 18 February 2016. Available from: <https://www.odonata central.org/docs/NWOL.pdf>. Accessed on: sept. $1,2018$.

Garrison, R. W.; Von Ellerieder, N. A.; Louton, J. A. Damselfly genera of the New World: An illustrated and annotated key to the Anisoptera. Baltimore: The John Hopkins University Press. 2006.

Garrison, R. W.; Von Ellerieder, N. A.; Louton, J. A. Damselfly genera of the New World: An illustrated and annotated key to the Zygoptera. Baltimore: The John Hopkins University Press, 2010.

Gibson, L.; Barret, B.; Burbidge, A. Dealing with uncertain absences in habitat modelling: A case study of a rare ground-dwelling parrot. Diversity and Distributions, v. 13, p. 704-713, 2007.

Gorham, C.; Vodopich, D. Effects of acidic pH on predation rates and survivorship of damselfly nymphs. Hydrobiologia, v. 242, no. 1, p.51-62, 1992. https://doi.org/ 10.1007/BF00017643

Grelle, C. E.; Fonseca, G. A. B.; Fonseca, M. T.; Costa, L. P. The question of scale in the threat analysis: A case study with Brazilian mammals. Animal Conservation, v. 2, p. 149-152, 1999. https://doi.org/10.1111/ j.1469-1795.1999.tb00060.x

Guisan, A.; Broennimann, O.; Engler, R.; Vust, M.; Yoccoz, N. G.; Lehmann, A.; Zimmermann, N. E. Using niche-based models to improve the sampling of rare species. Conservation Biology, v. 20, no. 2, p. 501-511, 2006. https://doi.org/10.1111/j.1523-1739.2006. 00354.x

ICMBio - Instituto Chico Mendes de Conservação da Biodiversidade. 2014. Disponível em: <http://www.icmbio.gov.br/ portal/faunabrasileira/estado-deconservacao/4831 odonata>. Accessed on: sept. 1, 2018.

IPEMA - Instituto de Pesquisas da Mata Atlântica. Conservação da Mata Atlântica no Estado do Espírito Santo: cobertura florestal e unidades de conservação. Vitória: IPEMA, 2005. (Programa Centros para Conservação da Biodiversidade, Conservação Internacional do Brasil).
IPES - Instituto de Apoio à Pesquisa e ao Desenvolvimento Jones dos Santos Neves. Espírito Santo, 2016. Disponível em: <http://www.ipes.es.gov.br/es/>. Accessed on: sept. 1, 2018.

Juen, L.; Oliveira-Junior, J. M. B.; Shimano, Y.; Mendes, T. P.; Cabette, H. S. R. Composição e riqueza de Odonata (Insecta) em riachos com diferentes níveis de conservação em um ecótone Cerrado-Floresta Amazônica. Acta Amazonica, v. 44, no. 2, p. 223-234, 2014. https://doi.org/10.1590/S0044-59672014 000200008

Lencioni, F. A. A. The damselflies of Brazil: An illustrated identification guide 1: NonCoenagrionidae families. São Paulo: All Print Editora, 2005.

Lencioni, F. A. A. The damselflies of Brazil: An illustrated identification guide 2 Coenagrionidae. São Paulo: All Print Editora, 2006.

Louzada, A. G.; Fonseca, I. R. Avaliação da qualidade de água do Rio Timbuí tendo como referência o grupo de coliformes. Serra: 2002.

Machado, A. B. M. Studies on Neotropical Protoneuridae. 10. Forcepsioneura lucia sp. n., from the Parque Estadual Rola Moça, Minas Gerais, Brazil (Odonata: Zygoptera). Boletim do Museu de Biologia MelloLeitão, Nova Serie, v. 11/12, p. 127-134, 2000.

Machado, A. B. M.; Drummond, G. M.; Paglia, A. P. Livro vermelho da fauna brasileira ameaçada de extinção. Brasília: MMA, Fundação Biodiversitas, 2008. (Biodiversidade, 19).

Machado, A. B. M. Livro vermelho das espécies ameaçadas de extinção da fauna de Minas Gerais. Belo Horizonte: Fundação Biodiversitas, 1998.

Mauri, J.; Oliveira, P.; Louzada, A. G.; Rocha, F. A.; Silva, J. O. Avaliação da degradação ambiental do Rio Timbuí, Município de Santa Teresa-ES. Anais do VIII Congresso de Ecologia do Brasil, Caxambu-MG, 2007.

May, M. L. Thermal adaptations of dragonflies, revisited. Advances in Odonatology, v. 5, p. 71-88, 1991.

Mendes, L. S.; Padovan, M. A Estação Biológica de Santa Lúcia, Santa Teresa, Espírito Santo. Boletim do Museu de 
Biologia Mello-Leitão, Nova Serie, v. 11/12, p. 7-34, 2000.

Merret, P.; Snazell, R. A comparison of pitfall trapping and vacuum sampling for assessing spiders on heathland at Ashdown Forest, South-East England. Bulletin of British Arachnological Society, v. 6, p. 1-13, 1983.

Mittermeier, C. G.; Fonseca, G. A. B.; Lamoreux, J.; Pilgrim, J.; Hoffman, M.; Gil, P. R.; Mittermeier, R.; Brooks, T. Hotspots revisited: Earth's biologically richest and most endangered terrestrial ecoregions. Cidade do Mexico: CEMEX, 2004.

MMA - Ministério do Meio Ambiente. Avaliação e identificação de áreas prioritárias para a conservação, utilização sustentável e repartição dos benefícios da biodiversidade dos biomas brasileiros. Brasília: MMA/SBF, 2003.

MMA - Ministério do Meio Ambiente. Lista Nacional das Espécies da Fauna Brasileira Ameaçadas de Extinção. 2014. Available from: <http://www.ibama.gov.br/documen tos/lista-de-especies-ameacadas-deextincao>. Accessed on: Sept. 1, 2018.

MMA - Ministério do Meio Ambiente. Portaria no 444, de 26 de novembro de 2018. Institui a estratégia nacional para conservação de espécies ameaçadas de extinção. Available from: <http://www.in. gov.br/materia/-/asset_publisher/

Kujrw0TZC2Mb/content/id/52249904/do12018-11-28-portaria-n-444-de-26-de-

novembro-de-2018-52249804>. Accessed on: Apr. 21, 2019.

Monteiro-Junior, C. S.; Juen, L.; Hamada, N. Analysis of urban impacts on aquatic habitats in the central Amazon basin: Adult odonates as bioindicators of environmental quality. Ecological Indicators, v. 48, p. 303-311, 2014. https://doi.org/10.1016/j.ecolind. 2014.08.021

Myers, N.; Mittermeier, R. A.; Mittermeier, C. G.; Fonseca, G. A. B.; Kent, J. Biodiversity hotspots for conservation priorities. Nature, v. 403 , p. $853-858,2000$. https://doi.org/ $10.1038 / 35002501$

Oliveira, J. M. B. 0 efeito da alteração ambiental sobre assembleias de Odonata na Amazônia Oriental. Nova Xavantina: Universidade do Estado de Mato Grosso, 2013. (Master dissertation).
Paglia, A. P. Panorama geral da fauna ameaçada de extinção no Brasil. In: Machado, A. B. M.; Soares, M. C.; Drummond, G. M. Lista da fauna brasileira ameaçada de extinção: incluindo a lista das quase ameaçadas e deficientes em dados. Belo Horizonte: Fundação Biodiversitas, 2005. p. 17-22.

Passamani, M.; Mendes, L. S. Espécies da fauna ameaçadas de extinção no Estado do Espírito Santo. Vitória: Instituto de Pesquisas da Mata Altântica, 2007.

Peruquetti, P. S.; De Marco, P. Efeito da alteração ambiental sobre a comunidade de Odonata em riachos de Mata Atlântica de Minas Gerais, Brasil. Revista Brasileira de Zoologia, v. 19, no. 2, p. 317-327, 2002.

Pimm, S. L.; Ayres, M.; Balmford, A.; Branch, G.; Brandon, K.; Brooks, T.; Bustamante, R.; Costanza, R.; Cowling, R.; Curran, L. M.; Dobson, A.; Farber, S.; Fonseca, G. A.; Gascon, C.; Kitching, R.; McNeely, J.; Lovejoy, T.; Mittermeier, R. A.; Myers, N.; Patz, J. A.; Raffle, B.; Rapport, D.; Raven, P.; Roberts, C.; Rodriguez, J. P.; Rylands, A. B.; Tucker, C.; Safina, C.; Samper, C.; Stiassny, M. L.; Supriatna, J.; Wall, D. H.; Wilcove, D. Environment: Can we defy nature's end? Science, v. 293, p. 2207-2208, 2001. https://doi.org/10.1126/science.1061626

Pinto, A. P. Odonata. In: Catálogo taxonômico da fauna do Brasil. PNUD, 2017. Available from: <http://fauna.jbrj.gov.br/fauna/fauna dobrasil/171>. Accessed on: Jun. 14, 2018.

Prendergast, J. R.; Quinn, R. M.; Lawton, J. H. The gaps between theory and practice in selecting nature reserves. Conservation Biology, v. 13, p. 484-492, 1999.

Prendergast, J. R.; Quinn, R. M.; Lawton, J. H.; Eversham, B. C.; Gibbons, D. W. Rare species, the coincidence of diversity hotspots and conservation strategies. Nature, v. 365, p. 335-337, 1993. https://doi.org/ $10.1038 / 365335 \mathrm{a} 0$

Rehn, A. Phylogenetic analysis of higher-level relationships of Odonata. Systematic Entomology, v. 28, p.181-239, 2003. https://doi.org/10.1046/j.1365-3113.2003. 00210.x

Santos, N. D. Contribuição ao conhecimento da fauna do Estado da Guanabara. 56. Notas sobre coenagriídeos (Odonata) que se criam em bromélias. Atas Sociedade de Biologia 
do Rio de Janeiro, v. 10 , no. 3, p. 83-85, 1966.

Simonelli, M.; Fraga, C. N. Espécies da flora ameaçadas de extinção no Estado do Espírito Santo. Vitória: IPEMA, 2007.

Thomaz, L. D.; Monteiro, R. Composição florística de encostas da Estação Biológica de Santa Lúcia, Município de Santa Teresa, ES. Boletim do Museu de Biologia MelloLeitão, Nova Serie, v. 7, p. 3-48, 1997.

Wise, D. H. Spiders in ecological webs. Cambridge: Cambridge University Press. 1993.

CC License information: This is an open-access article distributed under the terms of the Creative Commons Attribution License, which permits unrestricted use, distribution, and reproduction in any medium, provided the original work is properly cited. 